\title{
STUDY ON OUTPUT RESPONSE OF SUBMERGED ARC WELDING PROCESS
}

\author{
Aniruddha Ghosh, Ranjan Kumar Mitra
}

Preliminary communication Study on heat affected zone (HAZ) width is very essential for getting required weld quality. Minimization of HAZ width is urgent for high quality of weld. In present paper, an attempt has been made to find out relationship between process control factors and HAZ width. Optimum setting of processes parameters for getting minimum HAZ width with the help of Lagrangien multiplier method has also been attempted. Interaction effect of processes parameters on HAZ width have also been presented in graphical form. Good approximation of estimated HAZ width(s) has been revealed by comparing estimated and measured data.

Keywords: HAZ width; optimization through Lagrangien multiplier method; regression model; submerged arc welding process

Analiza izlazne reakcije postupka elektrolučnog zavarivanja pod zaštitnim slojem

Preliminary communication

Analiza širine zone pod utjecajem topline (ZUT) od bitne je važnosti za dobivanje željene kvalitete zavara. Što manja širina ZUT-a bitna je za visoku kvalitetu zavara. U ovom se radu nastojao pronaći odnos između čimbenika koji upravljaju postupkom i širine ZUT-a. Nasojalo se pronaći optimalan odnos parametara u postupku za postizanje minimalne širine ZUT-a uz pomoć metode Lagranževog multiplikatora. Interakcijski učinak parametara u postupku na širinu ZUT-a predstavljen je i u grafičkom obliku. Usporedbom procijenjenih i izmjerenih vrijednosti postignuta je dobra aproksimacija procijenjenim širinama ZUT-a.

Ključne riječi: model regresije; optimizacija metodom Lagranževog multiplikatora; postupak elektrolučnog zavarivanja pod zaštitnim slojem; širina ZUT-a

\section{Introduction}

Lots of critical input variables i.e. current, voltage, travel speed, sickout, wire feed rate, heat input etc. are involved in submerged arc welding process. With the change of input variables output variables i.e. heat affected zone width, hardness, microstructure, weld bead geometry etc. also change. In the application of SAW process, a common issue raises a concern about the uncertainties involved with the heat affected zone (HAZ) in and around the weldment. The most intriguing issue is about HAZ softening that imparts some uncertainties in the welded quality. It increases the probability of fatigue failures at the weakest zones caused by the heating and cooling cycle of the weld zone. It is observed that a refined microstructure of the HAZ imparts largely the intended properties of the welded joint [1]. For the case of SAW joint, engineers often face the problem to select the appropriate process control parameters for getting optimum value of HAZ width [2]. In order to bring out an appropriate combination of SAW parameters and a methodology to control such parameters an in depth investigation and characterization of HAZ softening zone is necessary to enrich this Submerged Arc Welding technology. The SAW process has drawn much attention, in recent time $[3 \div 8]$. With the view of achieving optimum settings of input parameters for minimum HAZ width, mathematical model has been developed for selecting correct and optimum settings of input variables by applying Lagrangien multiplier method. Interaction effect of processes parameters on HAZ width has also been presented in graphical form.

\section{Experimental procedure}

MEMCO semi-automatic welding machine with constant voltage, rectifier type power source with a 1200 A capacity was used to join mild steel plates $30 \times 15 \times 2$ cm. An ESAB SA1 (E8), 0,315 cm diameter, copper coated electrode and a basic fluoride type granular flux were used. The experiments were conducted as per the design matrix randomly to avoid errors due to noise factors. Two pieces of mild steel plates were cut and $\mathrm{V}$ groove of angle $60^{\circ}$ as per the standards were prepared. $0,1 \mathrm{~cm}$ root opening was selected to join the plates in the flat position keeping electrode positive and perpendicular to the plate. The job was firmly fixed to a base plate and then the submerged arc welding was finally carried out. The HAZ width has been measured with the help of optical research microscope (NEOPHOT-32) which is tabulated in Tab. 1.

\section{Development of mathematical model}

Let HAZ width/Heat Input be expressed as

$Y=a_{0}+a_{1} V+a_{2} F+a_{3} S+a_{4} N+a_{5} V^{2}+a_{6} F^{2}+a_{7} S^{2}+$
$+a_{8} N^{2}+a_{9} V F+a_{10} V S+a_{11} V N+a_{12} F S+a_{13} F N+a_{14} S N$

where, arc voltage is denoted by $V$, Wire Feed Rate is denoted by $F$, Travel Speed is denoted by $S$, Stick Out is denoted by $N$.

From the data of Tab. 1 and with the help of MATLAB coefficients $a_{0}, a_{1}, a_{3}, \ldots$ were calculated which are tabulated below (Tab. 2).

Calculation of Variance for testing has been made as shown in Tab. 3. It has been found from Tab. 3 that this regression model is adequate.

Optimization of HAZ width. This problem was assumed as constrained problem. Using Lagrangien multiplier method, optimum setting of input parameters of SAW process was obtained for minimum HAZ width.

The given procedure defines the Lagrangian method for identifying the stationary points of optimization problems with equality constraint. 
Let $L(X, \alpha)=f(X)-\alpha g(X)$

The function is called the Lagrangian function and the parameter $\alpha$ is the Lagrangean multiplier.

The equations

$\frac{\partial L}{\partial \alpha}=0 ; \quad$ and $\quad \frac{\partial L}{\partial X}=0$

give the necessary conditions for determining stationary points of $f(X)$ subject to $g(X)=0$.

For this problem,

$$
\begin{aligned}
& f(X)=1,04+0,02 V+0,15 F-0,165 S-0,05 N+ \\
& +0,04 V^{2}+0,07 F^{2}+0,08 S^{2}-0,01 N^{2}+0,03 V F+ \\
& +0,01 V S+0,03 V N-0,06 F S+0,04 F N+0,01 S N
\end{aligned}
$$

$$
\begin{aligned}
& g(X)=10+V+1,3 F-1,8 S-0,99 N+0,01 V^{2}- \\
& -0,25 F^{2}+0,25 S^{2}+0,01 N^{2}+0,18 V F-0,35 V S+ \\
& +0,02 V N-0,24 F S+0,11 F N-0,03 S N-Q=0
\end{aligned}
$$

where, $Q$ is the heat input, values of $Q$ are given in Tab. 1.

From Eqs. (2) and (3) it can be written that

$$
(0,08-0,02 \alpha) V+(0,03-0,18 \alpha) F+(0,01+0,35 \alpha) S+
$$$$
+(0,03-0,02 \alpha) N=\alpha-0,02
$$

$(0,03-0,18 \alpha) V+(0,14+0,5 \alpha) F+(-0,06+0,24 \alpha) S+$ $+(0,04-0,11 \alpha) N=1,3 \alpha-0,15$

$(0,01+0,35 \alpha) V+(-0,06+0,24 \alpha) F+(0,16+0,35 \alpha) S+$ $+(0,01-0,03 \alpha) N=-2,8 \alpha+0,16$

$(0,01-0,02 \alpha) V+(0,04-0,11 \alpha) F+(0,01+0,03 \alpha) S+$ $+(-0,02-0,02 \alpha) N=-0,99 \alpha+0,05$

By solving Eqs. (6) to (9), values $V, F, S, N$ and $\alpha$ were calculated. These values of $V, F, S, N$ are the optimum setting of input parameters corresponding minimum value of HAZ width which are tabulated in Tab. 4.

Optimization of HAZ width. Using Lagrangien multiplier method and putting the values of $Q$ from Tab. 2 and with the help of Eqs. (2) to (9), optimum setting of

\begin{tabular}{|c|c|c|c|c|c|c|}
\hline $\begin{array}{l}\text { Sl. } \\
\text { No. }\end{array}$ & $\begin{array}{l}\text { Arc Voltage } \\
\text { (volts) }\end{array}$ & $\begin{array}{l}\text { Wire Feed Rate } \\
(\mathrm{m} / \mathrm{min})\end{array}$ & $\begin{array}{l}\text { Travel Speed } \\
(\mathrm{m} / \mathrm{min})\end{array}$ & $\begin{array}{l}\text { Stick Out } \\
(\mathrm{mm})\end{array}$ & $\begin{array}{c}\text { Heat Input } \\
(\mathrm{kJ} / \mathrm{cm})\end{array}$ & $\begin{array}{l}\text { HAZ width } \\
(\mathrm{mm})\end{array}$ \\
\hline 1 & 27 & 1,5 & 0,70 & 38 & 6,9 & 1,00 \\
\hline 2 & 31 & 1,5 & 0,70 & 38 & 8,0 & 1,22 \\
\hline 3 & 25 & 1,2 & 0,65 & 36 & 6,9 & 1,16 \\
\hline 4 & 33 & 1,2 & 0,65 & 36 & 9,1 & 1,14 \\
\hline 5 & 29 & 0,8 & 0,65 & 36 & 8,0 & 0,92 \\
\hline 6 & 30 & 1,7 & 0,65 & 36 & 8,0 & 1,62 \\
\hline 7 & 28 & 1,2 & 0,45 & 36 & 11,6 & 1,68 \\
\hline 8 & 27 & 1,2 & 0,80 & 36 & 6,5 & 1,00 \\
\hline 9 & 29 & 1,2 & 0,65 & 30 & 8,0 & 1.04 \\
\hline 10 & 28 & 1,2 & 0,65 & 40 & 8,0 & 1,00 \\
\hline 11 & 29 & 1,2 & 0,65 & 36 & 8,0 & 1,01 \\
\hline 12 & 26 & 1,2 & 0,65 & 36 & 8,0 & 0,99 \\
\hline 13 & 27 & 1,2 & 0,65 & 36 & 8,0 & 0,96 \\
\hline 14 & 29 & 1,2 & 0,65 & 36 & 8,0 & 1,08 \\
\hline 15 & 29 & 1,2 & 0,65 & 36 & 8,0 & 1,03 \\
\hline 16 & 29 & 1,2 & 0,65 & 36 & 8,0 & 1,05 \\
\hline 17 & 29 & 1,2 & 0,65 & 36 & 8,0 & 1,16 \\
\hline
\end{tabular}
input parameters and coresponding value of minimum HAZ width has been calculated as depicted in Tab. 6 . Optimum settings of input parameters are $V=29$ volt, $F=$ $1,38 \mathrm{~m} / \mathrm{min}, S=0,51 \mathrm{~m} / \mathrm{min}, N=32,06 \mathrm{~mm}, Q=6,66$ $\mathrm{kJ} / \mathrm{cm}$ and $(\mathrm{HAZ})_{\min }=0,94 \mathrm{~mm}$.

Table 1 Observed values of HAZ width

\section{Result and discussion}

From Tab. 1 is has been revealed that if only heat input is increased then there is a tendency of increase of HAZ width as if heat input is increased then cooling time also increased for the welding so then there is chance of more grain growth as a result a tendency of increase of HAZ. It has also been found from Tab. 1 that stick out, voltage has negligible effect on HAZ width but travel speed has significant effect on HAZ width as if travel speed is increased then heat input is decreased so HAS width is decreased.

Interaction effect: Interaction effect between input parameters on HAZ width: According to Fig. 1, there is no major interaction effect present between input parameters arc voltage, wire feed rate/travel speed, arc voltage, /stick out and travel speed for HAZ width. But there are interaction effects present between wire feed rate, stick out/wire feed rate and travel speed. 
Table 2 Regression coefficient of models

Values of coefficient

\begin{tabular}{|c|c|c|c|}
\hline S1. No. & Coefficient & $\begin{array}{c}\text { Values of coefficient } \\
\text { for prediction of HAZ width }\end{array}$ & $\begin{array}{c}\text { Values of coefficient } \\
\text { for prediction of heat input }\end{array}$ \\
\hline 1 & $a_{0}$ & 1,04 & 10,00 \\
\hline 2 & $a_{1}$ & 0,02 & 1,00 \\
\hline 3 & $a_{2}$ & 0,15 & $-1,30$ \\
\hline 4 & $a_{3}$ & $-0,16$ & 0,99 \\
\hline 5 & $a_{4}$ & $-0,05$ & 0,01 \\
\hline 6 & $a_{5}$ & 0,04 & $-0,25$ \\
\hline 7 & $a_{6}$ & 0,07 & 0,25 \\
\hline 8 & $a_{7}$ & 0,08 & 0,01 \\
\hline 9 & $a_{8}$ & $-0,01$ & 0,18 \\
\hline 10 & $a_{9}$ & 0,03 & $-0,35$ \\
\hline 11 & $a_{10}$ & 0,01 & 0,02 \\
\hline 12 & $a_{11}$ & 0,03 & $-0,24$ \\
\hline 13 & $a_{12}$ & $-0,06$ & 0,11 \\
\hline 14 & $a_{13}$ & 0,04 & $-0,03$ \\
\hline 15 & $a_{14}$ & 0,01 & \\
\hline
\end{tabular}

Table 3 Calculation of Variance for testing the adequacy of the model

\begin{tabular}{|c|c|c|c|c|c|c|c|c|c|c|c|}
\hline \multirow{2}{*}{$\begin{array}{c}\text { Bead } \\
\text { parameter }\end{array}$} & \multicolumn{2}{|c|}{ First order term } & \multicolumn{2}{|c|}{ Second order term } & \multicolumn{2}{|c|}{ Lack of fit } & \multicolumn{2}{|c|}{ Error term } & \multirow[b]{2}{*}{$F$ ratio } & \multirow[b]{2}{*}{$R$ ratio } & \multirow{2}{*}{$\begin{array}{l}\text { Whether } \\
\text { model is } \\
\text { adequate }\end{array}$} \\
\hline & $S S$ & $D F$ & $S S$ & $D F$ & $S S$ & $D F$ & $S S$ & $D F$ & & & \\
\hline HAZ width & 1,18 & 4 & 0,4 & 10 & 0,08 & 10 & 0,03 & 6 & 1,9 & 5 & Adequate \\
\hline Heat Input & 139,1 & 4 & 8,1 & 10 & 1,75 & 10 & 0,3 & 6 & 3,2 & 183,6 & Adequate \\
\hline
\end{tabular}

Table 4 Optimum setting of input parameters and corresponding minimum value of HAZ width

\begin{tabular}{|c|c|c|c|c|c|c|c|}
\hline $\begin{array}{l}\text { Sl. } \\
\text { No. }\end{array}$ & $\begin{array}{c}\text { Arc voltage } \\
\text { (volts) }\end{array}$ & $\begin{array}{l}\text { Wire feed rate } \\
(\mathrm{m} / \mathrm{min})\end{array}$ & $\begin{array}{c}\text { Travel speed } \\
(\mathrm{m} / \mathrm{min})\end{array}$ & $\begin{array}{l}\text { Stick out } \\
(\mathrm{mm})\end{array}$ & $\begin{array}{c}\text { Lagrangean } \\
\text { multiplier }(\alpha)\end{array}$ & $\begin{array}{l}\text { Heat input } \\
(\mathrm{kJ} / \mathrm{cm})\end{array}$ & $\begin{array}{c}\text { HAZ width } \\
(\mathrm{mm})\end{array}$ \\
\hline 1 & 26 & 1,2 & 0,60 & 32 & 4,84 & 9,02 & 1,14 \\
\hline 2 & 27 & 1,0 & 0,62 & 34 & 2,46 & 11,60 & 1,25 \\
\hline 3 & 28 & 1,31 & 0,61 & 34 & 2,48 & 11,75 & 1,25 \\
\hline 4 & 29 & 1,39 & 0,52 & 32 & 4,59 & 14,38 & 1,26 \\
\hline 5 & 26 & 1,37 & 0,53 & 32 & 5,11 & 6,89 & 0,95 \\
\hline 6 & 27 & 1,37 & 0,52 & 32 & 4,25 & 7,48 & 1,00 \\
\hline 7 & 27 & 1,38 & 0,52 & 34 & 5,01 & 8,32 & 1,08 \\
\hline 8 & 27 & 1,31 & 0,63 & 34 & 2,49 & 10,14 & 1,21 \\
\hline 9 & 27 & 1,36 & 0,52 & 34 & 4,01 & 8,67 & 1,11 \\
\hline 10 & 27 & 1,32 & 0,61 & 33 & 3,48 & 11,11 & 1,24 \\
\hline 11 & 28 & 1,32 & 0,62 & 33 & 2,38 & 11,94 & 1,25 \\
\hline 12 & 29 & 1,38 & 0,52 & 32 & 5,59 & 14,65 & 1,26 \\
\hline 13 & 29 & 1,38 & 0,51 & 32.06 & 3,78 & 6,66 & 0,94 \\
\hline 14 & 28 & 1,38 & 0,50 & 33 & 3,77 & 6,91 & 0,96 \\
\hline 15 & 28 & 1,39 & 0,51 & 34 & 3,99 & 7,90 & 1,03 \\
\hline 16 & 27 & 1,34 & 0,63 & 34 & 3,49 & 10,18 & 1,21 \\
\hline
\end{tabular}

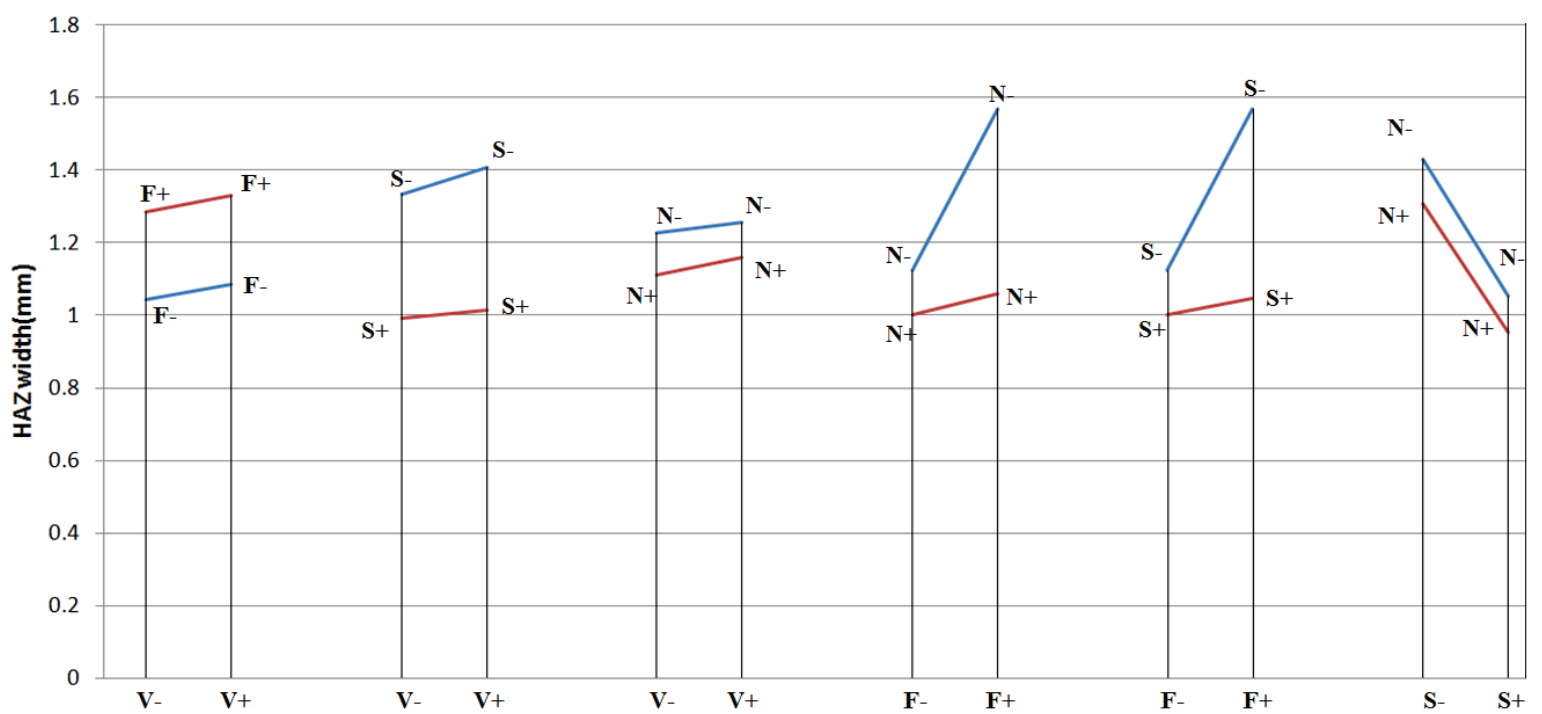

Figure 1 Interaction effect between input parameters on HAZ width (here, $V-=26$ volt, $V+=30$ volt, $F-=0,93 \mathrm{~m} / \mathrm{min}, F+=1,39 \mathrm{~m} / \mathrm{min}, S-=0,51$ $\mathrm{m} / \mathrm{min}, S+=0,67 \mathrm{~m} / \mathrm{min}, N-=32,50 \mathrm{~mm}, N+=37,50 \mathrm{~mm}$ ) 
Fig. 1 shows the HAZ width increases with increase of $F$ for all values of $S$, but the rate of increase in HAZ is steady and greater when $S$ is at its lower limit $(V-)$ level. This is because $F$ has a positive effect, but $\mathrm{S}$ has a negative effect on HAZ width, this is why rate of increase is much higher in $S$ - with respect to $S+$. Similarly $F$ has positive effect on $\mathrm{HAZ}$ width but $\mathrm{N}$ has negative effect on HAZ width, so rate of increase is much higher in $N$ - with respect to $\mathrm{N}+$. That is why interaction effects are present between wires feed rate, stick out/wire feed rate and travel speed.

\section{Conclusions}

Interaction effects are present between wires feed rate, stick out and travel speed. So, Lagrangien multiplier method is very useful for getting optimum settings of input factors of SAW process to get minimum HAZ width and high quality weld with respect to Taguchi's method.

\section{References}

[1] Murugan, N.; Gunaraj, V. Prediction and Control of Weld Bead Geometry and Shape Relationships in submerged arc welding of Pipes. // J. of Materials Processing Technology. 168, 3(2005). DOI: 10.1016/j.jmatprotec.2005.03.001

[2] Gunaraj, V.; Murugan, N. Prediction of Heat Affected Zone Characteristics in submerged Arc Welding of Structural Steel Pipes. // Welding Research, January 2002.

[3] Pathak, A. K.; Dutta, G. L. Three dimensional Finite Element Analysis to predict the different zones of Microstructure in Submerged Arc Welding, // Proc., Institution of Mechanical Engineers, part B, J. of Engineering Manufacture. 218, 3(2004). DOI: 10.1243/095440504322984821

[4] Kanjilal, P.; Majumdar, S. K.; Pal, T. K. Prediction of submerged arc weld-metal composition from flux ingredients with the help of statistical design of mixture experiment. // Scandinavian J. of Metallurgy. 33, 3(2004). DOI: 10.1111/j.1600-0692.2004.00679.x

[5] Kanjilal, P.; Pal, T. K.; Majumdar, S. K. Combined Effect of Flux and welding Parameters on Chemical Composition and Mechanical Properties of submerged arc Weld Metal. // J. of Materials Processing Technology.171, 2(2006). DOl: 10.1016/j.jmatprotec.2005.06.083

[6] Livieri, P.; Lazzarin, P. Fatigue strength of steel and aluminium welded joints based on generalised stress intensity factors and local strain energy values. // Int. J. of Fracture. 133, 3(2005). DOI: 10.1007/s10704-005-4043-3

[7] Bechet, G.; Kahraman, N. Wear Behaviour of Bulldozer Rollers Welded Using an arch submerged arc welding Process. // Materials \& Design. 24, 7(2003).

[8] Trindade, V. B.; Mello, R. S. T.; Payao, J. C.; Paranhos, R. P. R. Influence of Zirconium on Microstructure and Toughness of Low-Alloy Steel Weld Metals. // J. of Materials Engineering and Performance. 15, 3(2006), pp. 284-286. DOI: $10.1361 / 105994906 \times 108639$

\section{Authors' addresses}

Aniruddha Ghosh, Assistant Professor

Department of Mechanical Engineering

Government College of Engineering and Textile Technology Berhampore, West Bengal, India

E-mail: agmech74@gmail.com

Ranjan Kumar Mitra, Assistant Professor

Department of Mechanical Engineering

National Institute of Technology, Durgapur, West Bengal, India Mobile: +919434788148

E-mail: ranjan_kr_mitra@yahoo.com 